\title{
A Newly Discovered Babinski Sign in a Renaissance Painting
}

\author{
Laurent Tatu ${ }^{\mathrm{a}, \mathrm{b}}$

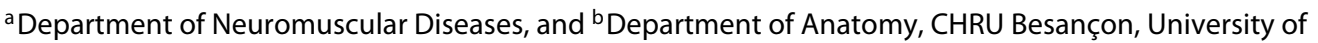 \\ Franche-Comté, Besançon, France
}
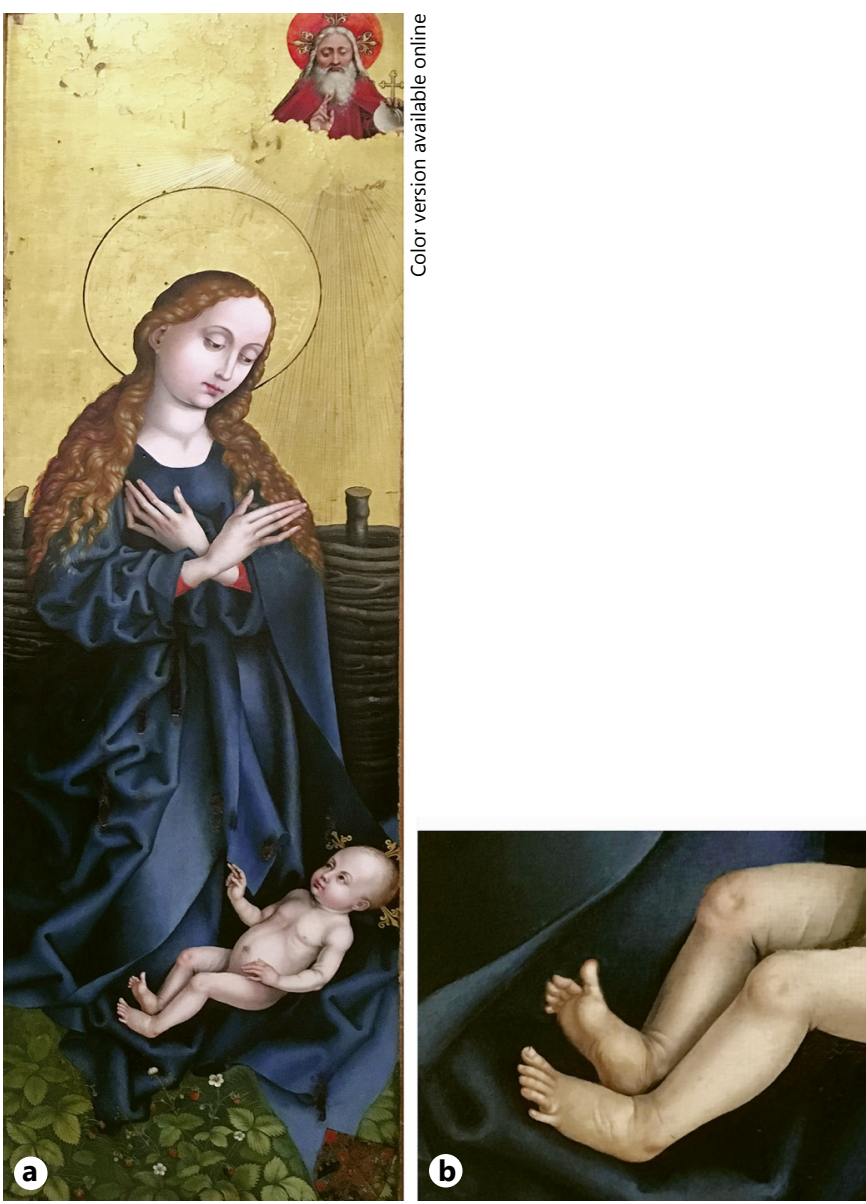

Fig. 1. a Martin Schongauer. Retable d'Orlier (Musée Unterlinden, Colmar, France). b Babinski sign (right foot).
Some examples of Babinski sign in Medieval and Renaissance paintings have already been noticed, especially involving newborns [1]. The most famous one appears on Madonna con il bambino e due angioli painted by Sandro Boticelli (ca. 1445-1510) [2].

We present here an unpublished case of Babinski sign in a Renaissance painting by Martin Schongauer (ca. 1450-1491), a German painter and engraver. Around 1470-1475, he painted one of his altarpieces, the Retable d'Orlier (Musée Unterlinden, Colmar, France; Fig. 1a). The Christ of the Nativity figuring on one of its surfaces exhibits a clear Babinski sign (Fig. 1b). In this case, it is a spontaneous sign that is not the consequence of a stimulation of the sole as in numerous cases already reported [1]. This spontaneous condition may be observed in newborns during the first months of life. Babinski sign appears clearly due to Schongauer's style. In his paintings, he usually represented characters with long and thin toes and fingers (see the Virgin hands).

\section{Disclosure Statement}

The author declares no conflicts of interest.

References

1 Massey EW, Sanders L: Babinski's sign in medieval, Renaissance, and baroque art. Arch Neurol 1989;46:85-88.

2 Cone TE Jr, Khoshbin S: Botticelli demonstrates the Babinski reflex more than 400 years before Babinski; pediatrics in art. AM J Dis Child 1978;132:188.

\section{KARGER}

() 2017 S. Karger AG, Basel

E-Mail karger@karger.com

www.karger.com/ene
Prof. Laurent Tatu

Department of Neuromuscular Diseases CHRU Besançon

3 Boulevard Fleming, FR-25000 Besançon (France)

E-Mail laurent.tatu@univ-fcomte.fr 